\title{
Activation of Nociceptin/Orphanin FQ Peptide Receptors Disrupts Visual but Not Auditory Sensorimotor Gating in BALB/cByJ Mice: Comparison to Dopamine Receptor Agonists
}

\author{
Aurelia Ces', David Reiss ${ }^{2}$, Ondine Walter ${ }^{2,3}$, Jürgen Wichmann ${ }^{4}$, Eric P Prinssen ${ }^{4}$, Brigitte L Kieffer ${ }^{2,5}$ \\ and Abdel-Mouttalib Ouagazzal*,2,6
}

'Mouse Clinical Institute, IIIkirch, France; ${ }^{2}$ IGBMC (Institut de Génétique et de Biologie Moléculaire et Cellulaire), Département de Neurobiologie et Génétique, Illkirch, France; ${ }^{3}$ Université Louis Pasteur, Strasbourg, France; ${ }^{4}$ PRED, Hoffmann-La Roche, Basel, Switzerland; Inserm, U596, IIIkirch, France; ${ }^{6}$ CNRS, UMR7 104, IIIkirch, France

Nociceptin/orphanin FQ (N/OFQ) peptide and its receptor (NOP receptor) have been implicated in a host of brain functions and diseases, but the contribution of this neuropeptide system to behavioral processes of relevance to psychosis has not been investigated. We examined the effect of the NOP receptor antagonists, Compound 24 and J-I 13397, and the synthetic agonist, Ro64-6198, on time function (2-2000 ms prepulse-pulse intervals) of acoustic ( $80 \mathrm{~dB} / 10 \mathrm{~ms}$ prepulse) and visual ( $1000 \mathrm{Lux} / 20 \mathrm{~ms}$ prepulse) prepulse inhibition of startle reflex (PPI), a preattentive sensory filtering mechanism that is central to perceptual and mental integration. The effects of the dopamine DI-like receptor agonist, SKF-81297, the D2-like receptor agonist, quinelorane, and the mixed DI/D2 agonist, apomorphine, were studied for comparison. When acoustic stimulus was used as prepulse, BALB/cBy] mice displayed a monotonic time function of PPI, and consistent with previous studies, apomorphine and SKF-8 I 279 induced PPI impairment, whereas quinelorane had no effect. None of the NOP receptor ligands was effective on acoustic PPI. When flash light was used as prepulse, BALB/cByJ mice displayed a bell-shaped time function of PPI and all dopamine agonists were active. Ro64-6198 was also effective in reducing visual PPI. NOP receptor antagonists showed no activity but blocked disruptive effect of Ro64-6198. Finally, coadministration of the typical antipsychotic, haloperidol, attenuated PPI impairment induced by Ro64-6198, revealing involvement of a dopaminergic component. These findings show that pharmacological stimulation of NOP or dopamine D2-like receptors is more potent in disrupting visual than acoustic PPI in mice, whereas DI-like receptor activation disrupts both. They further suggest that dysfunction of N/OFQ transmission may be implicated in the pathogenesis of psychotic manifestations.

Neuropsychopharmacology (2012) 37, 378-389; doi:I0.1038/npp.20 I I. 175; published online 3I August 20 I I

Keywords: NOP receptor; dopamine; startle reflex; prepulse inhibition; mice

\section{INTRODUCTION}

The nociceptin/orphanin $\mathrm{FQ}(\mathrm{N} / \mathrm{OFQ})$ peptide has been implicated in a host of brain functions and its receptor (NOP receptor: N/OFQ peptide receptor) represents an emerging target for pain, parkinsonism, anxiety, affective disorders, and cognitive decline (Calo' et al, 2000; Chiou et al, 2007; Gavioli and Calo', 2006; Lambert, 2008; Ko et al, 2009; Goeldner et al, 2010). For instance, deletion of genes coding for NOP receptor or endogenous N/OFQ peptide improves motor performances in naive mice (Ouagazzal et al, 2003; Marti et al, 2004; Viaro et al, 2008), whereas

*Correspondence: Dr A-M Ouagazzal, IGBMC (Institut de Génétique et de Biologie Moléculaire et Cellulaire), I Rue Laurent Fries, BP 10142 , Illkirch 67404, France, Tel: + 3338865 5664, Fax: + 3338865320 I, E-mail: abdel@igbmc.u-strasbg.fr

Received 18 April 201 I; revised 21 July 201 I; accepted 25 July 201 I pharmacological blockade of NOP receptor alleviates parkinsonian-like symptoms and enhances the effect of L-DOPA in rodent and nonhuman primate models of Parkinson's disease (PD) (Viaro et al, 2008; Visanji et al, 2008). Supporting evidence for the role of N/OFQ system in cognition has also been provided by numerous studies. Electrophysiological and neurochemical studies showed that N/OFQ suppresses neurotransmitter release (Schlicker and Morari, 2000; Cavallini et al, 2003; Meis, 2003; Kawahara et al, 2004) and synaptic plasticity (Manabe et al, 1998; Wei and Xie, 1999; Bongsebandhu-phubhakdi and Manabe, 2007) in various corticolimbic structures (eg, frontal cortex, hippocampus, and amygdale). Accordingly, NOP receptor agonists were consistently shown to disrupt cognitive performances in rodents, including working memory, spatial learning, fear conditioning, and recognition memory, whereas inhibition of N/OFQ transmission enhances learning performances (Manabe et al, 1998; Redrobe et al, 2000; 
Higgins et al, 2002; Mamiya et al, 2003; Roozendaal et al, 2007; Goeldner et al, 2008; Goeldner et al, 2009). Cognitive impairment is a core feature of schizophrenia and represents a major risk factor for development of psychotic manifestations in PD (Gold, 2004; Carter et al, 2008; Bora et al, 2009). The pattern of distribution of N/OFQ in corticolimbic circuits and its potent inhibitory actions on cognitive functions suggest that this neuropeptide may be implicated in the pathogenesis of psychosis. Yet, the potential contribution of N/OFQ-NOP receptor system to behavioral processes involving gating mechanisms has not been investigated.

The present study was designed to explore the role of NOP receptor in regulation of prepulse inhibition of startle (PPI). PPI provides an operational measure of sensorimotor gating and was shown to be deficient in patients suffering from schizophrenia and related psychotic disorders (Braff et al, 2001; Braff, 2010). Multiple approaches have been developed in rodents to mimic PPI impairments exhibited by schizophrenia patients. In the rats, PPI deficits caused by direct dopamine receptor agonists such as apomorphine were suggested to model aspects of psychosis that respond to typical antipsychotic treatments or dopamine D2 receptor antagonists (Swerdlow et al, 1994; Swerdlow and Geyer, 1998). In mice, the disruptive effect of apomorphine was attributed to an action on D1 instead of D2 receptors (Ralph-Williams et al, 2002), and in several mouse strains stimulation of D1 but not D2 receptors was shown to disrupt PPI (Ralph-Williams et al, 2003; Ralph and Caine, 2005). However, all these mouse studies relate to acoustic PPI only and to date it is unclear whether such differences between the function of D1 and D2 receptors generalize to other sensory modalities. Here, we studied for the first time the effects of a series of dopamine receptor agonists on both visual and acoustic PPI in mice, and extended this study to NOP receptor ligands. The effects of concomitant administration of NOP and dopamine receptor ligands were also examined to investigate possible functional interactions between N/OFQ and dopaminergic systems.

\section{MATERIALS AND METHODS}

\section{Animals}

Adult (14-20 weeks old) BALB/cByJ (BALB) and C57BL/6N (BL6) male mice (Charles River Laboratory, St-Germain-surl'Arbresle, France) were used. Mice were housed in groups of four on a $12 \mathrm{~h}$ light-dark cycle (lights off at 1900 hours) with water and food ad libitum. All experimental procedures were conducted with the approval of the local ethic committee (CREMEAS) based on adherence to European Union guidelines (European Community Guidelines on the Care and Use of Laboratory Animals 86/609/EEC).

\section{Prepulse Inhibition Apparatus and Testing}

Apparatus. Testing was conducted in eight startle devices (SRLAB, San Diego Instruments, San Diego, CA), each consisting of a Plexiglas cylinder $(5.1 \mathrm{~cm}$ outside diameter) mounted on a Plexiglas platform in a ventilated, soundattenuated cubicle with a high-frequency loudspeaker $(28 \mathrm{~cm}$ above the cylinder) producing both a continuous background noise and the various acoustic stimuli. The background noise of each chamber was set at $65 \mathrm{~dB}$. Movements within the cylinder were detected and transduced by a piezoelectric accelerometer attached to the Plexiglas base, digitized, and stored by a computer. Beginning at the stimulus onset, 65 readings of $1 \mathrm{~ms}$ were recorded to obtain the animal's startle amplitude. Auditory stimuli are burst of white noise $(0-20 \mathrm{KHz}$ and $0 \mathrm{~ms}$ rise-decay). A visual kit mounted on the top of the Plexiglas cylinder delivered the flashes of lights. The visual kit was similar in design to that provided by the San Diego Instruments and was fitted with 10 discrete white LEDs ( $5 \mathrm{~mm}$ in diameter $/ 5600$ m.c.d.; Marl International Optosource, Cumbria, Los Angeles, CA). Each visual kit was connected to an intensity modulator (made in-house), which allows change of the light intensity level. The optimal PPI parameters (eg, stimuli intensity and duration, prepulse-pulse intervals) were defined based on our previous validation studies (Aubert et al, 2006). Stimuli levels and piezoaccelerometer sensitivity were calibrated before each PPI session.

Behavioral testing. The test sessions for visual and acoustic PPI were identical to that described previously in detail (Aubert et al, 2006). Each session consisted of 125 trials presented in random order: a visual prepulse (VP, of different intensity and/or duration) or acoustic prepulse $(\mathrm{AP}, 80 \mathrm{~dB} / 10 \mathrm{~ms})$ presented at varying intervals $(2,10,20$, $50,100,200,500$, and $2000 \mathrm{~ms}$, prepulse offset to pulse onset) before the startling pulse (ST120: $120 \mathrm{~dB} / 40 \mathrm{~ms}$ ), ST120 alone, VP or AP alone, and background noise (BN). All trials were applied 10 times at an intertrial of $15 \mathrm{~s}$ in average. For visual PPI, mice were exposed to a short matching startle session prior to drug testing to ensure that animals were assigned into different groups of equivalent baseline startle and visual PPI. The matching PPI session was initiated with a 5 -min acclimation period followed by 5 successive startling pulses (ST120: $120 \mathrm{~dB} / 40 \mathrm{~ms}$ ) that were excluded from the analysis. Four different trial types were then presented: ST120, VP (1000 Lux) presented alone or $20 \mathrm{~ms}$ (prepulse offset to pulse onset) before the startle stimulus, and finally a BN to measure baseline motor activity in the cylinder. All trials were applied 10 times and presented in random order at an intertrial of $15 \mathrm{~s}$ in average. Each batch of mice was run through two or three independent PPI sessions with a period of at least 2 days between two successive sessions.

\section{Drugs}

Ro64-6198 (F Hoffmann La Roche, Basel, Switzerland), Compound 24 (BANORL-24), SKF-81297, quinpirole, and quinelorane (Tocris Bioscience, Bristole, UK) were disolved in saline. J-113397 (Tocris Bioscience) was disolved in saline solution containing 1\% Tween 80. Haloperidol (SigmaAldrich, St Quentin Fallavier, France) was prepared in saline with a drop of acetic acid, after which the $\mathrm{pH}$ was adjusted to 6-7 with a $5 \mathrm{~N}$ solution of sodium hydroxide. Apomorphine (Sigma-Aldrich) was dissolved in $0.1 \%$ ascorbic acid to prevent oxidation. Ro64-6198, compopund 24, and haloperidol were administered intraperitoneally (i.p.) $30 \mathrm{~min}$ before testing. Apomorphine was administred subcutaneously (s.c.) $5 \mathrm{~min}$ before testing. Quinelorane 
was injected i.p. 5 min before testing. SKF-81297 and quinpirole were administred i.p. $10 \mathrm{~min}$ before testing. J-113397 was administred i.p. 15 min before testing. For drug interaction studies the compounds were administred separately at the appropriate time point. Optimal pretreatment times and effective doses of each compounds were determined based on pilot experiments and published studies.

\section{Statistical Analysis}

PPI performance was expressed as percentage decrease in the amplitude of basal startle reflex caused by presentation of the prepulse (\% PPI). For analysis of dose-response effects of each compound on global PPI performances, mean \% PPI scores were pooled across all prepulse intervals $(2-2000 \mathrm{~ms})$. PPI data were analyzed using Student's $t$-test, and one-, two-, or three-way ANOVA as appropriate. The post-hoc comparisons were carried using Fisher's PLSD test when ANOVAs indicated statistically significant main or interaction effects. The accepted level of significance was $p<0.05$.

\section{RESULTS}

\section{Effects of Dopamine Agonists on Time Function of Acoustic PPI}

Figure 1 illustrates temporal pattern of PPI generated by an acoustic prepulse $(80 \mathrm{~dB} / 10 \mathrm{~ms})$ in BALB mice. In line with our previous findings (Aubert et al, 2006), BALB mice displayed a monotonic time function of acoustic PPI with a maximal startle inhibition occurring at the shortest interval (2 ms). Systemic administration of D1-like receptor agonist, SKF-81297 (5 and $10 \mathrm{mg} / \mathrm{kg}$ ) disrupts expression of acoustic PPI in BALB mice $(\mathrm{F}(2,17)=4.08, p<0.05$, Figure 1a). The post-hoc analysis revealed a significant effect of $5 \mathrm{mg} / \mathrm{kg}$ at 2 and $50 \mathrm{~ms}$ and a significant effect of $10 \mathrm{mg} / \mathrm{kg}$ at 2,10 , and $50 \mathrm{~ms}(p<0.05$, Fisher's PLSD test). Analysis of global PPI scores confirmed the disruptive effects of SKF81297 at both doses tested $(p<0.05$, Fisher's PLSD test, Figure $\left.1 a^{\prime}\right)$. SKF-81297 had no effect on startle response but it significantly increased baseline motor activity (in the cylinder) and reactivity to the acoustic prepulse $(p<0.05$, Fisher's PLSD test, Supplementary Table S1).

Consistent with previous findings (Ralph and Caine, 2005), administration of the D2-like receptor agonist, quinelorane, up to $3 \mathrm{mg} / \mathrm{kg}$ failed to disrupt expression of acoustic PPI in BALB mice $(\mathrm{F}(2,19)=0.33, p>0.05$, Figure $1 b$ and $\left.b^{\prime}\right)$. Quinelorane had no effect on reactivity to the acoutic prepulse but it significantly lowered baseline motor activity $(p<0.05$, Fisher's PLSD test, Supplementary Table S1). A clear tendency toward a reduction of startle response amplitude was also noted $(\mathrm{F}(2,19)=3.47$, $p=0.051$, Supplementary Table S1).

Like SKF-81297, apomorphine (3 and $10 \mathrm{mg} / \mathrm{kg}$ ) significantly reduced the expression of acoustic PPI in BALB mice $(\mathrm{F}(2,19)=4.0 \quad p<0.05$, Figure $1 \mathrm{c})$. The post-hoc analysis revealed a significant effect of $3 \mathrm{mg} / \mathrm{kg}$ at $2 \mathrm{~ms}$ and significant effects of $10 \mathrm{mg} / \mathrm{kg}$ at 2,20 , and $50 \mathrm{~ms}(p<0.05$, Fisher's PLSD test). Inspection of global PPI scores confirmed the disruptive effect of apomorphine only at the highest dose $\left(p<0.05\right.$, Fisher's PLSD test, Figure $\left.1 c^{\prime}\right)$.
From Supplementary Table S1 it can be seen that apomorphine significantly reduced startle amplitude at both doses tested ( $p<0.05$, Fisher's PLSD test). This agonist also tended to reduce baseline motor activity and to enhance reactivity to the acoustic prepulse, but the effects failed to reach statistical significance $(\mathrm{F}(2,19)=3.01, p=0.07$, and $\mathrm{F}(2,19)=2.75$, $p=0.08$, respectively, Supplementary Table $\mathrm{S} 1$ ).

\section{Effects of NOP Receptor Ligands on Time Function of Acoustic PPI}

Systemic administration of the selective NOP receptor antagonists, Compound 24 (3 and $10 \mathrm{mg} / \mathrm{kg}$, Goto et al, 2006 ) or J-113397 (1 and $3 \mathrm{mg} / \mathrm{kg}$, Ozaki et al, 2000) in BALB mice failed to modify expression of acoustic PPI $(\mathrm{F}(2,25)=0.03 p>0.05$ and $\mathrm{F}(2,18)=0.83, p>0.05$; Figure $2 \mathrm{a}$ and $\mathrm{b}$, respectively). Similarly, none of the NOP receptor antagonists changed baseline motor activity, reactivity to the prepulse, or startle response (Supplementary Table S2).

Systemic administration of the selective NOP receptor agonist, Ro64-6198 (Jenck et al, 2000), up to $3 \mathrm{mg} / \mathrm{kg}$ was without any effect on the expression of acoustic PPI $\left(\mathrm{F}(2,25)=0.02, p>0.05\right.$, Figure $2 \mathrm{c}$ and $\left.\mathrm{c}^{\prime}\right)$. This agonist also had no effects on baseline motor activity, reactivity to the prepulse, or startle response (Supplementary Table S2).

\section{Effects of Dopamine Agonists on Time Function of Visual PPI}

From Supplementary Figure S1 it can be seen that the time function of visual PPI generated by a bright flash (1000 Lux/20 ms) in BALB mice is a bell-shaped curve with a peak of inhibition at $20 \mathrm{~ms}$. In line with previous studies (Ison et al, 1992; Taylor et al, 1995; Ison, 2001; Aubert et al, 2006), decreasing prepulse intensity from 1000 to 50 Lux causes a delay in the onset of PPI that was reflected by loss of startle inhibition at $10 \mathrm{~ms}$ interval and displacement of the peak to $50 \mathrm{~ms}$ (Supplementary Figure S1A). Comparable results were obtained when prepulse (1000 Lux) duration was reduced from 20 to $10 \mathrm{~ms}$ (Supplementary Figure S1B). With these specific prepulse parameters, global PPI scores remained relatively unchanged $(p>0.05$, Student's $t$-test, Figure $1 \mathrm{a}^{\prime}$ and $\mathrm{b}^{\prime}$ ), but a significant decrease in the amount of inhibition was obtained when both intensity and duration of the flash light were reduced (eg, $300 \mathrm{Lux} / 10 \mathrm{~ms}$, data not shown). Based on these observations, we hypothesized that drug treatments that alter visual sensitivity independent of gating mechanisms would produce a delay in the onset of PPI as seen following decrement of the prepulse strength.

Systemic administration of SKF-81297 (3 and $10 \mathrm{mg} / \mathrm{kg}$ ) significantly reduced expression of visual PPI $(\mathrm{F}(2,31)=$ $3.34, p<0.05$, Figure 3a). Subsequent post-hoc analysis revealed a significant disruptive effect of 3 and $10 \mathrm{mg} / \mathrm{kg}$ at lead times ranging from 50 to 100 and 20 to $2000 \mathrm{~ms}$, respectively $(p<0.05$, Fisher's PLSD test). Inspection of global PPI performances confirmed the disruptive effects of SKF-81297 at all doses $(p<0.05$, Fisher's PLSD test, Figure $\left.3 \mathrm{a}^{\prime}\right)$. SKF-81297 had no effect on startle response $(\mathrm{F}(2,31)=1.39, \quad p>0.05)$ but it significantly increased baseline motor activity $(\mathrm{F}(2,31)=16.38, p<0.01$, Supplementary Table S3). 
Acoustic Prepulse Inhibition

a

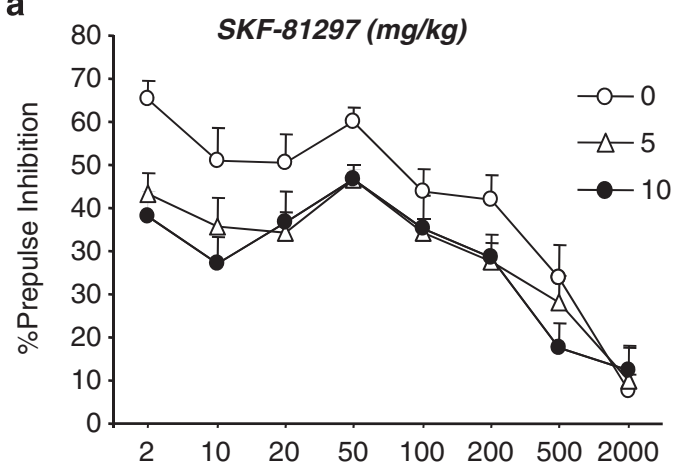

b

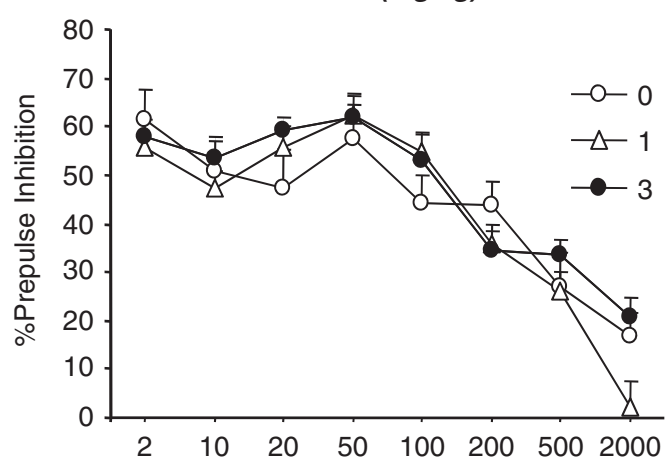

C

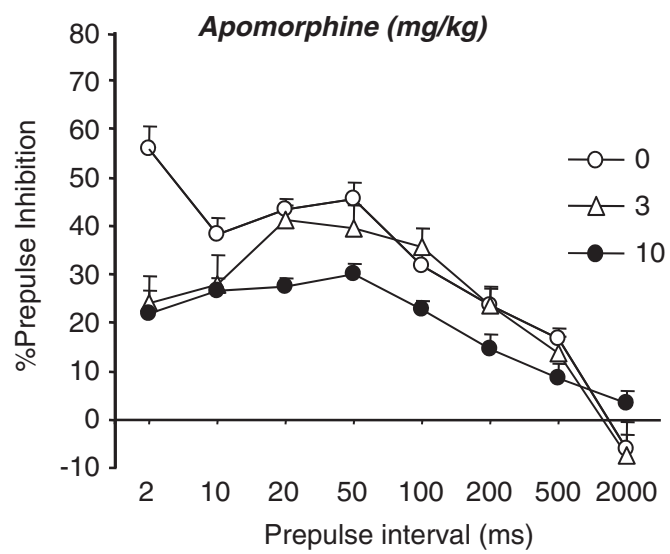

a'

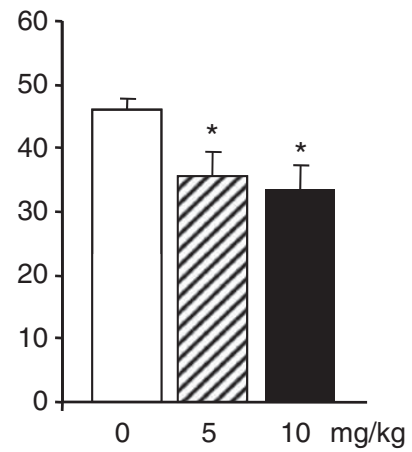

b'

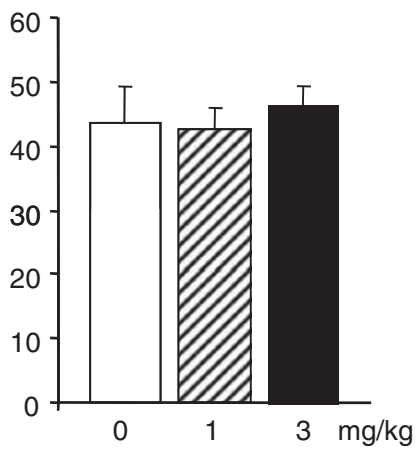

c'

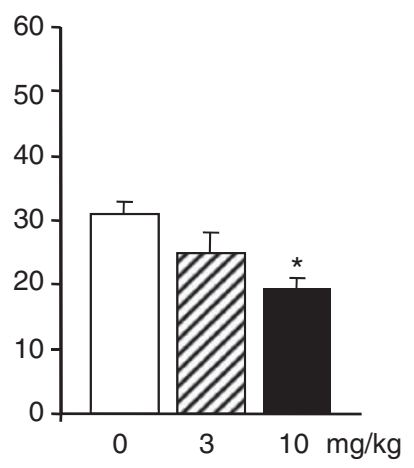

Figure I Effects of dopamine receptor agonists on acoustic PPI in BLAB mice. (a-c) Effects of SKF-8I297 (5 and $10 \mathrm{mg} / \mathrm{kg}$, i.p.), quinelorane (I and $3 \mathrm{mg} / \mathrm{kg}$, i.p.), and apomorphine (3 and $10 \mathrm{mg} / \mathrm{kg}$, s.c.) on expression of acoustic PPI, respectively. ( $\left.\mathrm{a}^{\prime}-\mathrm{c}^{\prime}\right)$ Global PPI scores averaged across all prepulse intervals. Acoustic prepulse $(80 \mathrm{~dB} / 10 \mathrm{~ms})$ was presented at varying intervals $(2-2000 \mathrm{~ms})$ before an acoustic pulse $(I 20 \mathrm{~dB} / 40 \mathrm{~ms})$. * $p<0.05$, significantly different from corresponding control group (Fisher's PLSD post-hoc test). Values are mean of \% PPI \pm SEM.

Systemic administration of quinelorane $(0.1,0.3$, and $1 \mathrm{mg} / \mathrm{kg}$ ) dose dependently decreased the expression of visual PPI (Figure 3b). At the $10 \mathrm{~ms}$ interval, startle inhibition was completely suppressed by quinelorane as seen following decrement of the visual prepulse strength. Overall ANOVA revealed a significant effect of treatment $(\mathrm{F}(3,29)=3.89$, $p<0.05$, Figure 3b) and subsequent post-hoc analysis indicated that 0.1 and $0.3 \mathrm{mg} / \mathrm{kg}$ reduced PPI at 10 and $50 \mathrm{~ms}$, whereas $1 \mathrm{mg} / \mathrm{kg}$ impaired PPI at $2000 \mathrm{~ms}$ and at all other intervals ranging from 2 to $100 \mathrm{~ms}(p<0.05$, Fisher's PLSD test). Inspection of global PPI scores confirmed the disruptive effects of quinelorane at 0.3 and $1 \mathrm{mg} / \mathrm{kg}$ doses $\left(p<0.05\right.$, Fisher's PLSD test, Figure $\left.3 b^{\prime}\right)$. From Supplementary Table S3, it can be seen that quinelorane reduced startle response magnitude at the highest dose $(p<0.05$, Fisher's PLSD test). This agonist also tended to reduce baseline motor activity but the effect just fell short of statistical significance $(\mathrm{F}(3,29)=2.86, p=0.054$, Supplementary Table S3).

Supplementary Figure S1C illustrates the effect of D2-like agonist, quinpirole, on time function of visual PPI. Like quinelorane, $10 \mathrm{mg} / \mathrm{kg}$ quinpirole caused a slight delay in the onset of PPI that was reflected by the loss of startle 
Acoustic Prepulse Inhibition

a

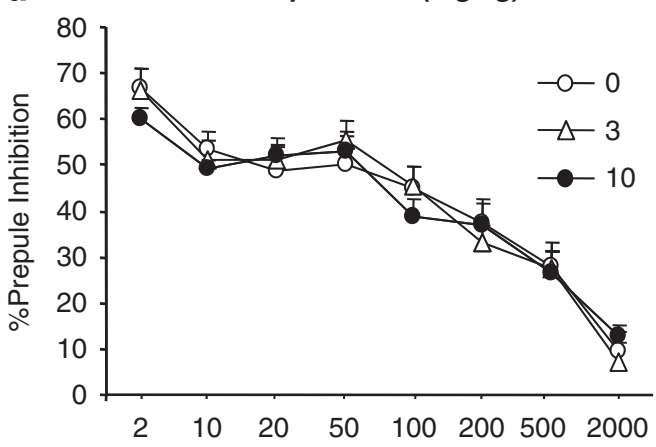

b

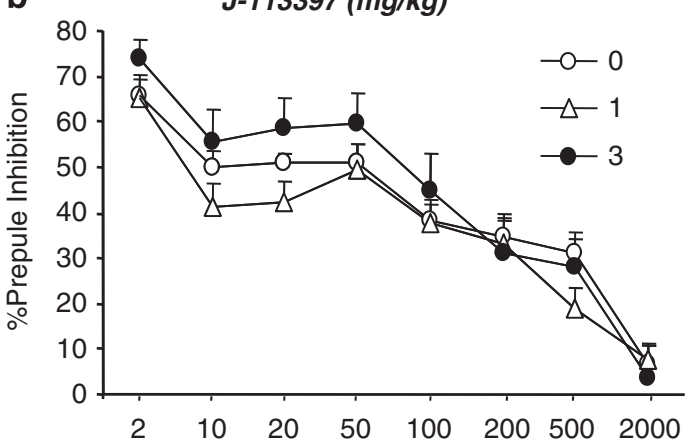

C

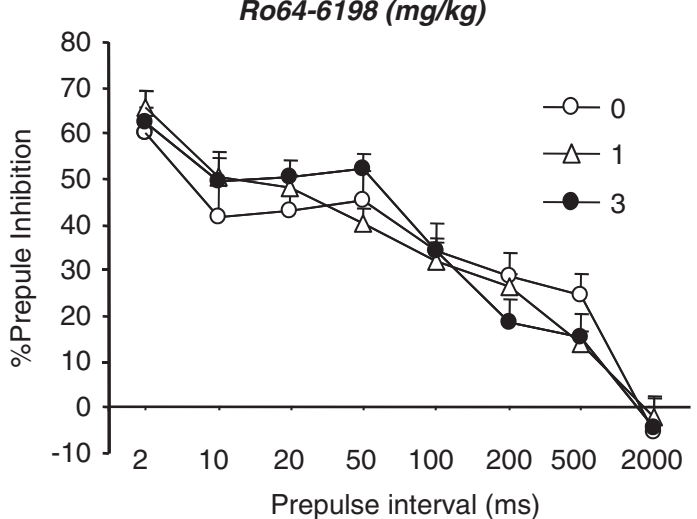

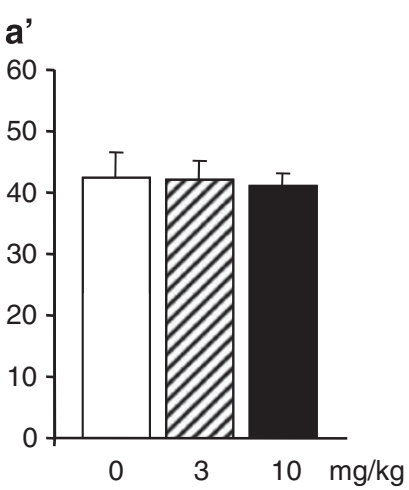

b'

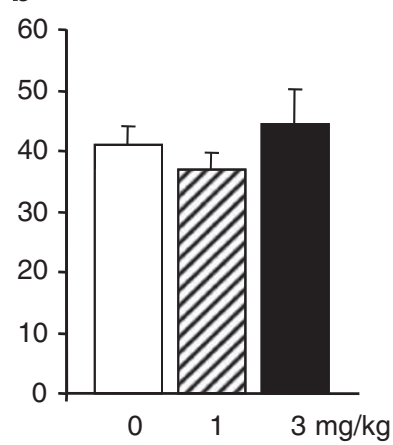

c'

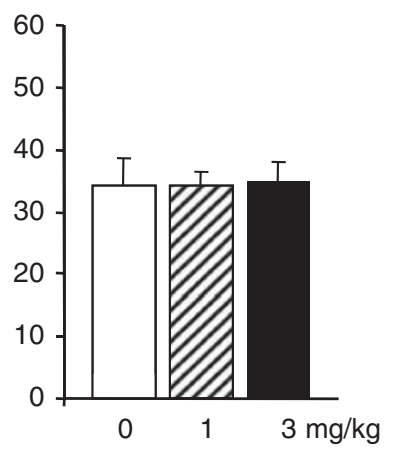

Figure 2 Effects of NOP receptor ligands on acoustic PPI in BALB mice. (a-c) Effects of Compound 24 (3 and I0 mg/kg, i.p.), J-I I 3397 (I and 3 mg/ $/ \mathrm{kg}$, i.p.), and Ro64-6198 (I and $3 \mathrm{mg} / \mathrm{kg}$, i.p.) on expression of acoustic PPI, respectively. $\left(\mathrm{a}^{\prime}-\mathrm{c}^{\prime}\right)$ Global PPI scores averaged across all prepulse intervals. Acoustic prepulse $(80 \mathrm{~dB} / 10 \mathrm{~ms})$ was presented at varying intervals $(2-2000 \mathrm{~ms})$ before an acoustic pulse $(120 \mathrm{~dB} / 40 \mathrm{~ms})$. Values are mean of \% PPI $\pm \mathrm{SEM}$.

inhibition at $10 \mathrm{~ms}$ interval. Analysis of global scores revealed a significant disruptive action of this agonist on PPI $(p<0.05$, Student's $t$-test, Supplementary Figure S1C). A significant reduction in startle response was also detected (vehicle $(n=8): 450 \pm 38$ and quinpirole $(n=7): 281 \pm 23$, $p<0.05$, Student's $t$-test).

The above findings show that $\mathrm{D} 1$ receptor activation is more potent in reducing visual PPI at intermediate $(20-100 \mathrm{~ms})$ and long intervals $(\geqslant 200 \mathrm{~ms})$, whereas D2 receptor activation produces disruption essentially at short $(2-10 \mathrm{~ms})$ and intermediate intervals. We then examined whether concomitant stimulation of D1 and D2 receptors with the mixed agonist, apomorphine, could recapitulate the full pattern of deficits obtained with SKF-81297 and quinelorane. As expected, apomorphine (1 and $3 \mathrm{mg} / \mathrm{kg}$ ) produced PPI impairment across a wide range of prepulse intervals (Figure 3c). Again, startle inhibition was wiped out at $10 \mathrm{~ms}$ interval as seen with D2-like agonists. Two-way ANOVA revealed a significant effect of treatment $(\mathrm{F}(2,34)=10.17, p<0.05$, Figure $3 \mathrm{c})$ and post-hoc analysis indicated that $1 \mathrm{mg} / \mathrm{kg}$ apomorphine impaired PPI at 10 and $50 \mathrm{~ms}$, whereas $3 \mathrm{mg} / \mathrm{kg}$ disrupted PPI at all intervals ranging from 10 to $500 \mathrm{~ms} \quad(p<0.05$, Fisher's PLSD test). Inspection of global PPI scores confirmed the disruptive effects of both doses tested $(p<0.05$, Fisher's PLSD test, Figure $\left.3 c^{\prime}\right)$. Apomorphine had no effect on baseline motor activity $(\mathrm{F}(2,34)=1.26, p>0.05)$, but it significantly lowered startle response magnitude at the highest dose $(p<0.05$, Fisher's PLSD test, Supplementary Table S3). 
Visual Prepulse Inhibition
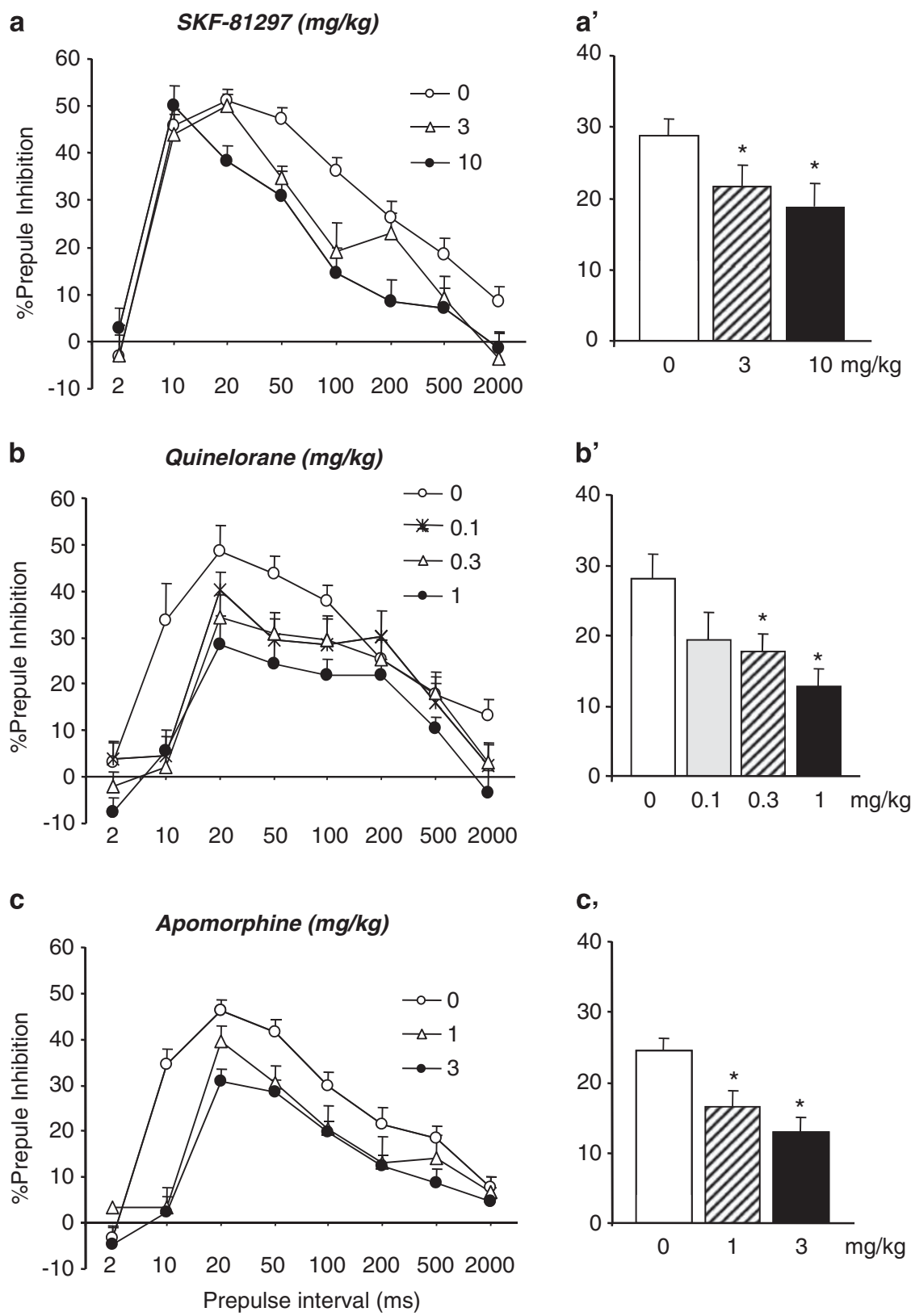

Figure 3 Effects of dopamine receptor agonists on visual PPI in BALB mice. (a-c) Effects of DI-like agonist, SKF-8I 297 (3 and I0 mg/kg, i.p.), D2-like agonist, quinelorane (0.I, 0.3 , and I mg/kg, i.p.), and the mixed DI/D2 agonist, apomorphine (I and $3 \mathrm{mg} / \mathrm{kg}$, s.c.), on expression of visual PPI, respectively. $\left(a^{\prime}-c^{\prime}\right)$ Global PPI scores averaged across all prepulse intervals. Visual prepulse ( 1000 Lux/20 ms) was presented at varying intervals (2-2000 ms) before an acoustic pulse $(120 \mathrm{~dB} / 40 \mathrm{~ms})$. * $p<0.05$, significantly different from corresponding control group (Fisher's PLSD post-hoc test). Values are mean of \% $\mathrm{PPI} \pm \mathrm{SEM}$.

\section{Effects of NOP Receptor Ligands on Time Function of Visual PPI}

As can be seen from Figure 4, systemic administration of Compound 24 ( 3 and $10 \mathrm{mg} / \mathrm{kg}$ ) or J-113397 ( 1 and $3 \mathrm{mg} / \mathrm{kg}$ ) had no effect on the expression of visual PPI in BALB mice $(\mathrm{F}(2,27)=0.38 p>0.05$ and $\mathrm{F}(2,20)=2.28, p>0.05$ for Figure $4 \mathrm{a}$ and $\mathrm{b}$, respectively). None of the antagonists changed baseline motor activity or startle response magnitude (Supplementary Table S4).
Systemic administration of Ro64-6198 $(0.3$ and $1 \mathrm{mg} / \mathrm{kg})$ produced a dose-dependent reduction of visual PPI (Figure 4c). The effect of Ro64-6198 was uniform across prepulse intervals, indicating that it did not interfere with visual prepulse detection. Two-way ANOVA revealed a significant effect of treatment $(\mathrm{F}(2,36)=3.85, p<0.05)$ and post-hoc analysis indicated that $0.3 \mathrm{mg} / \mathrm{kg}$ significantly reduced PPI at $10 \mathrm{~ms}$, whereas $1 \mathrm{mg} / \mathrm{kg}$ disrupted PPI at intervals ranging from 2 to $50 \mathrm{~ms}(p<0.05$, Fisher's PLSD test). Analysis of global PPI scores confirmed the disruptive 
Viusal Prepulse Inhibition
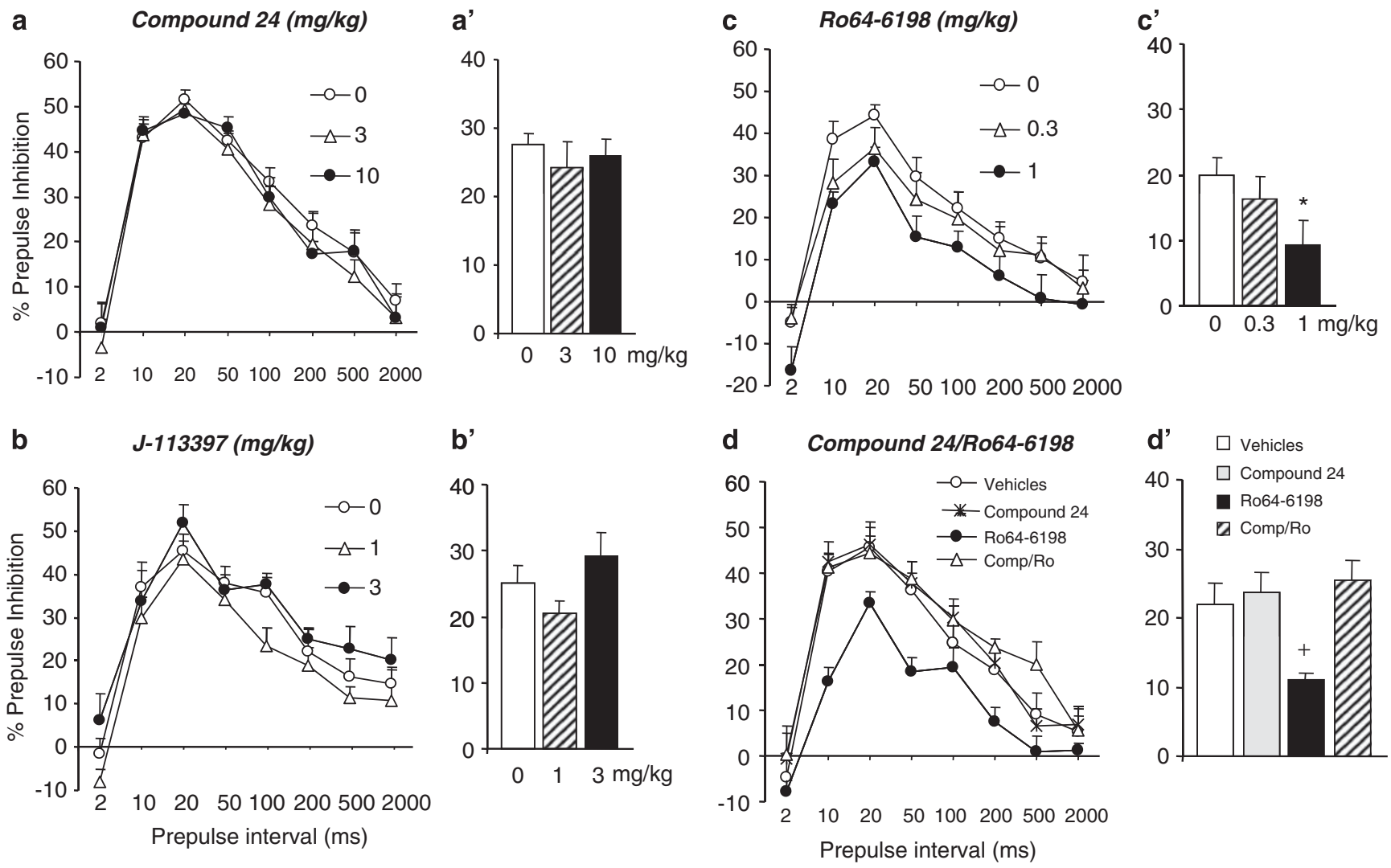

Figure 4 Effects of NOP receptor ligands on visual PPI in BALB mice. (a-c) Effects of the NOP receptor antagonists, Compound 24 (3 and I0 mg/kg, i.p.) and J-I I 3397 (I and 3 mg/ $/ \mathrm{kg}$, i.p.), and the synthetic agonist, Ro64-6I98 (0.3 and I mg/kg, i.p.), on expression of visual PPI, respectively. (a'-c' $)$ Global PPI scores averaged across all prepulse intervals. (d) Effect of coadministration of Compound 24 (5 mg/kg, i.p.) and Ro64-6 I98 (I.5 mg/kg, i.p.) on expression of visual PPI. (d') Global PPI scores. Visual prepulse ( 1000 Lux/20 ms) was presented at varying intervals (2-2000 ms) before an acoustic pulse (I $20 \mathrm{~dB} / 40 \mathrm{~ms}$ ). * and,$+ p<0.05$, significantly different from corresponding control group and significantly different from all other groups, respectively (Fisher's PLSD post-hoc test). Values are mean of $\% \mathrm{PPI} \pm \mathrm{SEM}$.

action of the highest dose $(p<0.05$, Fisher's PLSD test, Figure $\left.4 c^{\prime}\right)$. No effect of Ro64-6198 was detected on baseline motor activity or startle reflex response $(\mathrm{F}(2,36)<2.0$, $p>0.05$ for both parameters, Supplementary Table S4).

We then examined whether Ro64-6198 impairs visual PPI through NOP receptor activation. As expected, Ro64-6198 $(1.5 \mathrm{mg} / \mathrm{kg})$ reduced PPI across a wide range of prepulse intervals and coadministration of Compound $24(5 \mathrm{mg} / \mathrm{kg})$ completely reversed this effect (Figure 4d). Analysis of global PPI scores revealed a significant effect of Ro64-6198 $(\mathrm{F}(1,27)=8.63, p<0.05)$ and a significant Compound $24 \times$ Ro64-6198 interaction $\left(\mathrm{F}(1,27)=5.26, p<0.05\right.$, Figure $\left.4 \mathrm{~d}^{\prime}\right)$. Subsequent post-hoc analysis confirmed that only animals that received Ro64-6198 treatment displayed a significantly lower PPI scores compared with all other groups $(p<0.05$, Fisher's PLSD test, Figure $\left.4 \mathrm{~d}^{\prime}\right)$. None of the pharmacological treatment modified baseline motor activity or startle response $(p>0.05$, two-way ANOVA, Supplementary Table S4).

\section{Effects of Coadministration of NOP and Dopamine Receptor Ligands on Visual PPI}

We first examined whether the disruptive effect of Ro64-6198 on PPI involved a dopaminergic component.
To this end, we used a short PPI session (the matching startle session, see Materials and Methods) in which visual prepulse was presented $20 \mathrm{~ms}$ before the pulse (a prepulse-pulse interval that corresponds to peak PPI in our conditions). As seen in Figure 5a, Ro64-6198 (1.5 mg/kg) significantly reduced visual PPI in BALB mice $(\mathrm{F}(1,24)=7.09, p<0.05)$. Blockade of dopamine receptors with haloperidol $(0.5 \mathrm{mg} / \mathrm{kg})$ had no effect on its own but prevented PPI impairment induced by Ro64-6198 $(\mathrm{F}(1,24)=6.79, p<0.05)$. The post-hoc analysis confirmed that only animals that received Ro64-6198 treatment displayed a significantly lower PPI scores compared with all other groups $(p<0.05$, Fisher's PLSD test). None of the pharmacological treatments modified startle response but Ro64-6198 significantly increased baseline activity in this experiment $(p<0.05$, two-way ANOVA, Supplementary Table S5). We then verified whether haloperidol could reverse Ro64-6198 effect across a wide range of intervals. Based on temporal profiles of activity of dopamine agonists (Figure 2), the interaction between haloperidol and Ro646198 was analyzed across short $(2-20 \mathrm{~ms})$, intermediate (20$100 \mathrm{~ms})$, and long (200-2000 ms) intervals. From Supplementary Figure S2A, it can be seen that haloperidol was effective against Ro64-6198 at specific prepulse intervals. Two-way ANOVA with repeated measures revealed a signi- 
Viusal Prepulse Inhibition

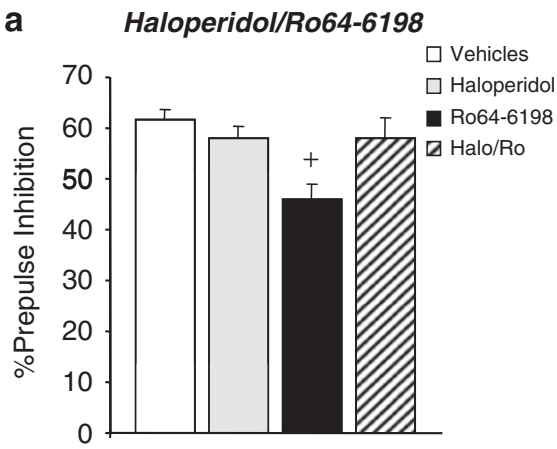

b Compound 24/Quinelorane

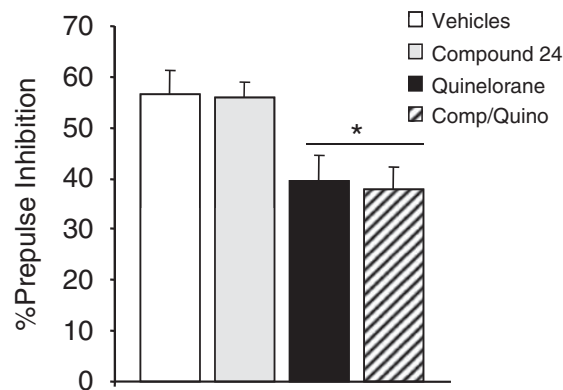

\section{Compound 24/Apomorphine}

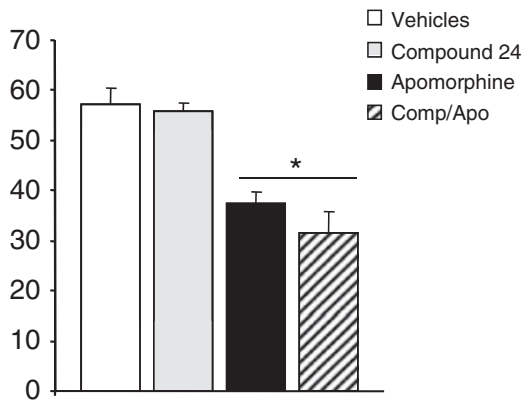

d Haloperidol/Apomorphine

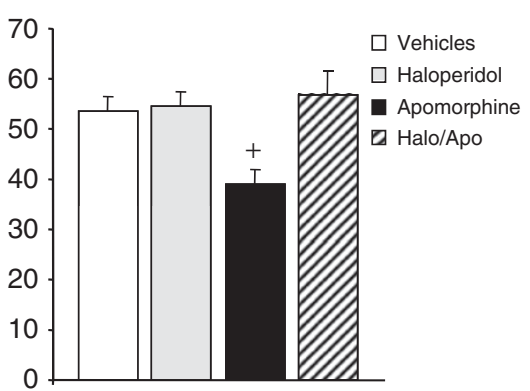

Figure 5 Effects of coadministration of NOP and dopamine receptor ligands on visual PPI in BALB mice. (a) Effects of concomitant administration of Ro64-6198 (1.5 mg/kg, i.p.) and the typical neuroleptic, haloperidol (0.5 mg/kg, i.p.), on visual PPI. (b) Effects of concomitant administration of quinelorane ( I mg/kg, i.p.) and Compound 24 (I $0 \mathrm{mg} / \mathrm{kg}$, i.p.) on visual PPI. (c) Effects of concomitant administration of apomorphine (3 mg/ $/ \mathrm{kg}, \mathrm{s.c}$.$) and Compound 24$ ( $10 \mathrm{mg} / \mathrm{kg}$, i.p.) on visual PPI. (d) Effects of concomitant administration of apomorphine ( $2 \mathrm{mg} / \mathrm{kg}$, s.c.) and haloperidol $(0.3 \mathrm{mg} / \mathrm{kg}$, i.p.) on visual PPI. Visual prepulse (I $000 \mathrm{Lu} / 20 \mathrm{~ms})$ was presented $20 \mathrm{~ms}$ before the acoustic pulse $(120 \mathrm{~dB} / 40 \mathrm{~ms})$. * and,$+ p<0.05$, significantly different from corresponding control group and significantly different from all other groups group, respectively (Fisher's PLSD post-hoc test). Values are mean of \% PPI \pm SEM.

ficant effect of Ro64-6198 across intervals $((\mathrm{F} 2,124)=11.01$, $p<0.05)$ and a significant haloperidol $\times$ Ro64-6198 $\times$ interval interaction $((\mathrm{F} 2,124)=3.40, p<0.05)$. Subsequent analysis using two-way ANOVA confirmed that haloperidol reversed Ro64-6198 effect at intermediate intervals $((\mathrm{F} 1,62)=38.08, \quad p<0.05)$. Haloperidol also tended to reduce Ro64-6198 effect at long intervals but the interaction just fell short of statistical significance $((F 1,62)=3.35$, $p=0.07)$.

We next examined whether dopamine agonists disrupt visual PPI through NOP receptor-dependent mechanism. We first studied the effect of NOP receptor blockade on PPI deficit induced by the D2-like receptor agonist quinelorane (Figure $5 \mathrm{~b}$ ). Once again, systemic administration of quinelorane $(1 \mathrm{mg} / \mathrm{kg})$ impaired visual PPI $(\mathrm{F}(1,25)=16.40$, $p<0.05)$ and coadministration of the NOP receptor antagonist, Compound $24(10 \mathrm{mg} / \mathrm{kg})$, failed to modify this effect $(\mathrm{F}(1,25)=0.01, p>0.05)$. Quinelorane had no effect on baseline activity, but tended to reduce startle response $(\mathrm{F}(1,25)=3.89, p=0.059$, Supplementary Table S5).

We then examined whether NOP receptor antagonists could modify behavioral deficits induced by the mixed D1/D2 agonist, apomorphine (Figure 5c). As expected, apomorphine $(3 \mathrm{mg} / \mathrm{kg})$ significantly reduced visual PPI $(\mathrm{F}(1,39)=51.72, p<0.05$, Figure $5 \mathrm{~b})$. Compound $24(10 \mathrm{mg} / \mathrm{kg})$ had no effects on its own $(\mathrm{F}(1,39)=1.44, p>0.05)$ and also failed to modify the PPI deficit induced by apomorphine $(F(1,39)=0.56, p>0.05)$. Similar results were obtained when J-113397 (5 mg/kg) was coadministered with apomorphine (Supplementary Figure S2B).

Finally, to confirm that apomorphine-induced disruption of visual PPI is sensitive to an antipsychotic treatment, we used haloperidol as a reference compound (Figure 5d). Coadministration of haloperidol $(0.3 \mathrm{mg} / \mathrm{kg})$ had no effect on its own on visual PPI but fully reversed the deficit induced by apomorphine $(\mathrm{F}(1,24)=5.69, p<0.05$ for haloperidol $\times$ apomorphine interaction).

\section{DISCUSSION}

The present study investigated (1) the contribution of the NOP receptor system to modulation of sensorimotor gating by two different sensory modalities (ie, light and tone), (2) a comparison of the effects of NOP receptor ligands with those of dopamine receptor agonists, and (3) cross-talk between these systems. Dopamine has long been associated with psychosis because virtually all effective and clinically used antipsychotic drugs act as blockers of dopamine receptors, in particular D2-like receptors (Baldessarini and Tarazi, 1996; Seeman, 2010). Accordingly, PPI impairments seen in schizophrenic patients can be mimicked in rats by administration of D2 but not D1 receptor agonists (Geyer et al, 2001). In mice, D2-like receptor agonists are less effective in reducing PPI. In many inbred and outbred mouse strains, PPI impairments are caused by administration of D1 instead 
of D2 agonists (Ralph-Williams et al, 2003; Ralph and Caine, 2005; Geyer, 2006; but see Ralph and Caine, 2007). Here we show that disruptive effects of D2 receptor activation depend on the sensory modality of the prepulse. Both the D1-like receptor agonist, SKF-81297, and the D2like receptor agonist, quinelorane, dose dependently impaired visual PPI, but only the former agonist was effective on acoustic PPI. These results corroborate studies showing that D1 receptors play a more prominent role than D2 receptors in modulation of acoustic PPI in mice (see above). More importantly, they show that visual PPI is highly sensitive to D2 receptor perturbations. The latter effects cannot be attributed to nonspecific changes in startle responses. In BALB mice, 0.1 and $0.3 \mathrm{mg} / \mathrm{kg}$ quinelorane impaired the expression of visual PPI, whereas it had no detectable effect on startle responses, and in BL6 strain it failed to reduce acoustic PPI despite its depressive action on startle response (Supplementary Figure S3, see also Ralph and Caine, 2005). Similarly, it is unlikely that PPI deficits induced by the D1 agonist, SKF-81297, may be secondary to its motor stimulant effects because apomorphine mimicked the disruptive action of this agonist on acoustic PPI without increasing baseline motor activity. Collectively, these observations support the view that distinct neural pathways underly expression of PPI, startle reflex response, and locomotor activity (Ouagazzal et al, 2001a, b; Ralph et al, 2001; Ralph-Williams et al, 2003; Ralph and Caine, 2005; Chang et al, 2010).

Previous studies in rats showed that alterations in visual function produce unique temporal pattern of effect in visual PPI paradigms (for review, see Ison, 2001). Progressive photoreceptor degeneration causes a delay in the onset of PPI accompanied by a gradual decrease in the amount of inhibition generated by the visual prepulse (Wecker and Ison, 1986; Ison et al, 1992; DiLoreto et al, 1995; Ison et al, 1998; Ison, 2001). In the early stages of retinal damage, the delay is reflected by the loss of startle inhibition at short intervals and the shift of the peak toward intermediate intervals, whereas maximal level of inhibition remains relatively unchanged (Ison et al, 1992; Ison, 2001). Here, we show that decrements of visual prepulse strength produces a comparable pattern of effect, demonstrating that our testing conditions are optimal for detecting changes in visual sensitivity. As demonstrated by numerous studies, dopamine is an important chemichal messenger in the sensory visual system (Richfield et al, 1989; Witkovsky, 2004; Brandies and Yehuda, 2008; Kawai et al, 2011) and it was shown to facilitate adaptation to ambient light (Witkovsky, 2004; Nir et al, 2002; Ichinose and Lukasiewicz, 2007), which raises the possibility that deficits we saw in visual PPI may partly be because of reduced sensitivity to the flash light. Closer examination of the temporal pattern of effects of dopamine agonists suggests that this may possibly be the case for D2 agonists. Indeed, quinelorane and quinpirole caused a slight delay in the onset of visual PPI as seen following decrement of the prepulse strength, thus suggesting that $\mathrm{D} 2$ receptor activation may have reduced detection and/or temporal processing of the visual prepulse. Interestingly, both agonists also impaired PPI at intermediate lead times (20-100 ms), a temporal window that corresponds to maximum startle inhibition. On the contrary, SKF-81297 was especially potent at prepulse intervals starting from 20 to $2000 \mathrm{~ms}$. The lack of effect at short intervals suggests that D1 receptor activation alters the gating process rather than visual sensitivity. The pattern of effects we obtained with the mixed D1/D2 agonist, apomorphine, corroborate these observations. Like SKF81297, apomorphine reduced visual PPI at prepulse intervals above $100 \mathrm{~ms}$. On the other hand, it caused a slight delay in the onset of visual PPI, thus mimicking the effect of D2-like agonists. These findings extend previous studies showing that apomorphine disrupts visual PPI in rats (Campeau and Davis, 1995; Taylor et al, 1995; Weber and Swerdlow, 2008). However, they contrast with those reported by Taylor et al (1995) suggesting a lack of effect of apomorphine on visual sensitivity. The discripency between the two studies may relate to difference in species and parametric conditions used to establish visual PPI. For instance, Taylor et al (1995) used only four lead times (40, 70,110 , and $220 \mathrm{~ms}$ ) with long temporal gaps between each (30-40 ms), which may explaine their failure in detecting subtle delay (eg, $10 \mathrm{~ms}$ ) in the onset of PPI as that seen in the current study. In view of the above findings, it emerges that $\mathrm{D} 1$ receptor activation specifically disrupts the gating process, whereas D2 receptor activation may alter visual PPI through dual mechanisms: an indirect mechanism involving attenuation of prepulse detection/temporal processing and a direct mechanism involving disruption of the gating process. However, further studies using electroretinogram are needed to confirm the possible effects of D2-like agonists on visual function.

N/OFQ and NOP receptors are densely expressed in neuronal circuits (eg, prefrontal cortex, hippocampus, amygdala, thalamus, globus palludus) subserving sensorimotor gating (Swerdlow et al, 2001; Darland and Grandy, 1998), but their contribution to regulation of PPI has not been demonstrated. Here, we show for the first time that stimulation of NOP receptors with the synthetic agonist, Ro64-6198, impairs expression of visual PPI. Ro64-6198 caused no shift in time function of PPI, which rules out an effect of this agonist on prepulse detectability, and no changes in startle response or baseline motor activity were observed at effective doses. Collectively, these results argue for specific disruption of the gating mechanism triggered by the visual prepulse. Unexpectedly, however, the NOP receptor agonist was ineffective in reducing acoustic PPI in BALB mice. The null finding cannot be attributed to the fact that BALB mice exhibit abnormal (monotonic) time function of acoustic PPI. We have also tested BL6 strain, which displays a normal (bell shaped) time function of acoustic PPI (Aubert et al, 2006), and found no effects of either Ro64-6198 or quinelorane (Supplementary Figure S3). The close resemblance between the profiles of activity of these agonists raises the possibility that NOP and dopamine receptors may modulate visual PPI through common neural targets. Accordingly, coadministration of the dopamine receptor antagonist, haloperidol, attenuates PPI deficit induced by Ro64-6198, thus revealing the existence of a functional cooperation between N/OFQ and dopamine. However, the exact nature and sites of the functional relationship between these neurotransmitters need to be clarified. It is worth noting that N/OFQ produces bidirectional dose-dependent effects on locomotor behaviors in rodents. At low doses it increases locomotor exploration, whereas at 
high doses it reduces it, and both behavioral effects were shown to involve dopamine mechanisms (Florin et al, 1996; Lutfy et al, 2001; Kamei et al, 2004; Kuzmin et al, 2004; Marti et al, 2004; Narayanan et al, 2004). At the dose-range tested (0.3-1.5 mg/kg), Ro64-6198 if anything tended to increase locomotor behavior (Supplementary Tables S4 and S5; see also Goeldner et al, 2008), which suggests that this agonist may disrupt visual PPI by enhancing dopamine release (Konya et al, 1998). However, the lack of effect of this agonist on acoustic PPI argues against this possibility and suggests that Ro64-6198 may disrupt visual PPI via a postsynaptic action on dopaminoreceptive circuits. In this context, dopamine may primarily play a permissive role in the expression of deleterious action of Ro64-6198 (or N/OFQ) on PPI.

Blockade of NOP receptor signaling represents promising therapeutic strategy for a range of neuropsychiatric diseases, including chronic pain, parkinsonism, affective disorders, and cognitive decline (Chiou et al, 2007; Gavioli and Calo', 2006; Lambert, 2008; Goeldner et al, 2008, 2009, 2010). The fact that pharmacological blockade of NOP receptors failed to disrupt PPI or to potentiate disruptive effects of apomorphine or quinelorane is therefore of great interest as it suggests that NOP receptor antagonists may be less prone to produce perceptual disturbances like dopamine agonists. Conversely, overstimulation of NOP receptors may perhaps be linked to the development of such complications, at least regarding visual processing. The attenuation of behavioral effect of Ro64-6198 by haloperidol further supports a possible role of endogenous N/OFQ in the pathogenesis of psychotic manifestations. Psychosis is not unique to schizophrenia but can also occur as a result of disease or drug use. For instance, visual hallucinations are the core criteria for clinical diagnosis of dementia with Lewy body (DLB, dementia along with parkinsonism; Weintraub and Hurtig, 2007). Visual hallucinations are also the most frequent psychotic manifestations in PD and their appearance was linked to the use of dopamine agonists and to the presence of comorbid vulnerabilities, such as cognitive disturbances and dementia (for review, see Weintraub and Hurtig, 2007; Fénelon, 2008; Zahodne and Fernandez, 2008). It is worth noting that excessive secretion of N/OFQ was suggested to be one component of the pathophysiological processes that contribute to development of parkinsonism. Brain interstitial levels of N/OFQ peptide are higher in PD and antagonism of NOP receptors alleviates parkinsonianlike symptoms in rodent and nonhuman primate models of PD (Marti et al, 2005, 2007, 2010; Viaro et al, 2008; Visanji et al, 2008; Volta et al, 2010, 2011). Given the potent suppressive action of this neuropeptide on synaptic plasticity and cognitive processing (see Introduction), it is tempting to speculate that in $\mathrm{PD}$ and perhaps DLB, enhanced circulating levels of N/OFQ may be one possible mechanistic link between parkinsonism, cognitive impairments, and vulnerability to psychosis. In this respect, selective targeting of NOP receptor may offer interesting possibilities for management of parkinsonism with better side-effect profile than existing therapies.

In conclusion, the present study shows that stimulation of NOP or dopamine D2 receptors disrupts visual, but not acoustic, PPI in mice. It also reveals the existence of functional interactions between NOP and dopamine receptor systems on the regulation of sensorimotor gating.
Acoustic PPI is the most widely used paradigm for phenotyping genetically modified mice and exploring genetic mechanisms of behavioral traits relevant to complex psychiatric diseases such as schizophrenia (Powell et al, 2009). The differential effect of NOP and D2 receptor stimulations on visual and acoustic PPI provides new evidence that distinct neural substrates govern intramodal and cross-modal PPI and emphasizes the need of using multiple sensory modalities for tackling neural mechanisms of sensorimotor gating.

\section{ACKNOWLEDGEMENTS}

This work was supported by grants from the Centre National de la Recherche Scientifique (CNRS), the Institut National de la Santé et de la Recherche Médicale (INSERM), the Universite Louis Pasteur de Strasbourg (ULP), the Agence Nationale de la Recherche (Grant SynapticZinc), and the National Institute of Drug Abuse Grant (DA05010).

\section{DISCLOSURE}

The authors declare no conflict of interest.

\section{REFERENCES}

Aubert L, Reiss D, Ouagazzal AM (2006). Auditory and visual prepulse inhibition in mice: parametric analysis and strain comparisons. Genes Brain Behav 5: 423-431.

Baldessarini RJ, Tarazi FI (1996). Brain dopamine receptors: a primer on their current status, basic and clinical. Harv Rev Psychiatry 3: 301-325.

Bongsebandhu-phubhakdi S, Manabe T (2007). The neuropeptide nociceptin is a synaptically released endogenous inhibitor of hippocampal long-term potentiation. J Neurosci 27: 4850-4858.

Bora E, Yücel M, Pantelis C (2009). Cognitive impairment in schizophrenia and affective psychoses: implications for DSM-V criteria and beyond. Schizophr Bull 36: 36-42.

Braff DL (2010). Prepulse inhibition of the startle reflex: a window on the brain in schizophrenia. Curr Top Behav Neurosci 4: 349-371.

Braff DL, Geyer MA, Swerdlow NR (2001). Human studies of prepulse inhibition of startle: normal subjects, patient groups, and pharmacological studies. Psychopharmacology 156: 194-215.

Brandies R, Yehuda S (2008). The possible role of retinal dopaminergic system in visual performance. Neurosci Biobehav Rev 32: 611-656.

Calo’ G, Guerrini R, Rizzi A, Salvadori S, Regoli D (2000). Pharmacology of nociceptin and its receptor: a novel therapeutic target. Br J Pharmacol 129: 1261-1283.

Campeau S, Davis M (1995). Prepulse inhibition of the acoustic startle reflex using visual and auditory prepulse: disruption by apomorphine. Psychopharmacology 117: 267-274.

Carter CS, Barch DM, Buchanan RW, Bullmore E, Krystal JH, Cohen J et al (2008). Identifying cognitive mechanisms targeted for treatment development in schizophrenia: an overview of the first meeting of the Cognitive Neuroscience Treatment Research to Improve Cognition in Schizophrenia Initiative. Biol Psychiatry 64: 4-10.

Cavallini S, Marino S, Beani L, Bianchi C, Siniscalchi A (2003). Nociceptin inhibition of acetylcholine efflux from different brain areas. NeuroReport 14: 2167-2170.

Chang WL, Geyer MA, Buell MR, Weber M, Swerdlow NR (2010). The effects of pramipexole on prepulse inhibition and locomotor activity in C57BL/6J mice. Behav Pharmacol 21: 135-143. 
Chiou LC, Liao YY, Fan PC, Kuo PH, Wang CH, Riemer C et al (2007). Nociceptin/orphanin FQ peptide receptors: pharmacology and clinical implications. Curr Drug Targets 8: 117-135.

Darland T, Grandy DK (1998). The orphanin FQ system: an emerging target for the management of pain? Br J Anaesth 81: 29-37.

DiLoreto Jr D, Ison JR, Bowen GP, Cox C, del Cerro M (1995). A functional analysis of the age-related degeneration in the Fischer 344 rat. Curr Eye Res 14: 303-310.

Fénelon G (2008). Psychosis in Parkinson's disease: phenomenology, frequency, risk factors, and current understanding of pathophysiologic mechanisms. CNS Spectr 13(Suppl 4): 18-25.

Florin S, Suaudeau C, Meunier JC, Costentin J (1996). Nociceptin stimulates locomotion and exploratory behaviour in mice. Eur J Pharmacol 317: 9-13.

Gavioli EC, Calo' G (2006). Antidepressant- and anxiolytic-like effects of nociceptin/orphanin FQ receptor ligands. Naunyn Schmiedebergs Arch Pharmacol 372: 319-330.

Geyer MA (2006). The family of sensorimotor gating disorders: comorbidities or diagnostic overlaps? Neurotox Res 10: 211-220.

Geyer MA, Krebs-Thomson K, Braff DL, Swerdlow NR (2001). Pharmacological studies of prepulse inhibition models of sensorimotor gating deficits in schizophrenia: a decade in review. Psychopharmacology 156: 117-154.

Goeldner C, Reiss D, Kieffer BL, Ouagazzal AM (2010). Endogenous nociceptin/orphanin-FQ in the dorsal hippocampus facilitates despair-related behavior. Hippocampus 20: 911-916.

Goeldner C, Reiss D, Wichmann J, Kieffer BL, Ouagazzal AM (2009). Activation of nociceptin opioid peptide (NOP) receptor impairs contextual fear learning in mice through glutamatergic mechanisms. Neurobiol Learn Mem 91: 393-401.

Goeldner C, Reiss D, Wichmann J, Meziane H, Kieffer BL, Ouagazzal AM (2008). Nociceptin receptor impairs recognition memory via interaction with NMDA receptor-dependent mitogen-activated protein kinase/extracellular signal-regulated kinase signaling in the hippocampus. J Neurosci 28: 2190-2198.

Gold JM (2004). Cognitive deficits as treatment targets in schizophrenia. Schizophr Res 72: 21-28.

Goto Y, Arai-Otsuki S, Tachibana Y, Ichikawa D, Ozaki S, Takahashi $\mathrm{H}$ et al (2006). Identification of a novel spiropiperidine opioid receptor-like 1 antagonist class by a focused library approach featuring 3D-pharmacophore similarity. J Med Chem 49: 847-849.

Higgins GA, Kew JN, Richards JG, Takeshima H, Jenck F, Adam G et al (2002). A combined pharmacological and genetic approach to investigate the role of orphanin FQ in learning and memory. Eur J Neurosci 15: 911-922.

Ichinose T, Lukasiewicz PD (2007). Ambient light regulates sodium channel activity to dynamically control retinal signaling. J Neurosci 27: 4756-4764.

Ison JR (2001). The acoustic startle reflex in the mouse: reflex elicitation and reflect modification by preliminary stimuli. In: Willott JF (ed). Handbook of Mouse Auditory Research: From Behavior to Molecular Biology, Ch. 5, CRC Press: Boca Raton. pp 59-82.

Ison JR, Bowen GP, del Cerro M (1992). Impoverished stimulus input does not simulate the slowed visual kinetics of retinal damage. Invest Ophthalmol Vis Sci 33: 3114-3120.

Ison JR, Bowen GP, del Cerro M (1998). A behavioral study of temporal processing and visual persistence in young and aged rats. Behav Neurosci 112: 1273-1279.

Jenck F, Wichmann J, Dautzenberg FM, Moreau JL, Ouagazzal AM, Martin JR et al (2000). Synthetic agonist at the orphanin FQ/ nociceptin receptor ORL1: anxiolytic profile in the rat. Proc Natl Acad Sci USA 97: 4938-4943.

Kamei J, Matsunawa Y, Miyata S, Tanaka S, Saitoh A (2004). Effects of nociceptin on the exploratory behavior of mice in the holeboard test. Eur J Pharmacol 489: 77-87.
Kawahara Y, Hesselink MB, van Scharrenburg G, Westerink BH (2004). Tonic inhibition by orphanin FQ/nociceptin of noradrenaline neurotransmission in the amygdala. Eur J Pharmacol 485: 197-200.

Kawai F, Horiguchi M, Miyachi E (2011). Dopamine modulates the voltage response of human rod photoreceptors by inhibiting the h current. Invest Ophthalmol Vis Sci 52: 4112-4117.

Ko MC, Woods JH, Fantegrossi WE, Galuska CM, Wichmann J, Prinssen EP (2009). Behavioral effects of a synthetic agonist selective for nociceptin/orphanin FQ peptide receptors in monkeys. Neuropsychopharmacology 34: 2088-2096.

Konya H, Masuda H, Itoh K, Nagai K, Kakishita E, Matsuoka A (1998). Modification of dopamine release by nociceptin in conscious rat striatum. Brain Res 788: 341-344.

Kuzmin A, Sandin J, Terenius L, Ogren SO (2004). Evidence in locomotion test for the functional heterogeneity of ORL-1 receptors. Br J Pharmacol 141: 132-140.

Lambert DG (2008). The nociceptin/orphanin FQ receptor: a target with broad therapeutic potential. Nat Rev Drug Discov 7: 694-710.

Lutfy K, Do T, Maidment NT (2001). Orphanin FQ/nociceptin attenuates motor stimulation and changes in nucleus accumbens extracellular dopamine induced by cocaine in rats. Psychopharmacology 154: 1-7.

Mamiya T, Yamada K, Miyamoto Y, Konig N, Watanabe Y, Noda Y et al (2003). Neuronal mechanism of nociceptin-induced modulation of learning and memory: involvement of N-methyl-D-aspartate receptors. Mol Psychiatry 8: 752-765.

Manabe T, Noda Y, Mamiya T, Katagiri H, Houtani T, Nishi M et al (1998). Facilitation of long-term potentiation and memory in mice lacking nociceptin receptors. Nature 394: 577-581.

Marti M, Mela F, Fantin M, Zucchini S, Brown JM, Witta J et al (2005). Blockade of nociceptin/orphanin FQ transmission attenuates symptoms and neurodegeneration associated with Parkinson's disease. J Neurosci 25: 9591-9601.

Marti M, Mela F, Veronesi C, Guerrini R, Salvadori S, Federici M et al (2004). Blockade of nociceptin/orphanin FQ receptor signaling in rat substantia nigra pars reticulata stimulates nigrostriatal dopaminergic transmission and motor behavior. J Neurosci 24: 6659-6666.

Marti M, Sarubbo S, Latini F, Cavallo M, Eleopra R, Biguzzi S et al (2010). Brain interstitial nociceptin/orphanin FQ levels are elevated in Parkinson's disease. Mov Disord 25: 1723-1732.

Marti M, Trapella C, Viaro R, Morari M (2007). The nociceptin/ orphanin FQ receptor antagonist J-113397 and L-DOPA additively attenuate experimental parkinsonism through overinhibition of the nigrothalamic pathway. J Neurosci 27: 1297-1307.

Meis S (2003). Nociceptin/orphanin FQ: actions within the brain. Neuroscientist 9: 158-168.

Narayanan S, Lam H, Carroll FI, Lutfy K (2004). Orphanin FQ/ nociceptin suppresses motor activity through an action along the mesoaccumbens axis in rats. J Psychiatry Neurosci 29: 116-123.

Nir I, Harrison JM, Haque R, Low MJ, Grandy DK, Rubinstein M et al (2002). Dysfunctional light-evoked regulation of cAMP in photoreceptors and abnormal retinal adaptation in mice lacking dopamine D4 receptors. J Neurosci 22: 2063-2073.

Ouagazzal A-M, Grottick AJ, Moreau J-L, Higgins GA (2001a). Effect of LSD on prepulse inhibition and spontaneous behaviour in the rat: a pharmacological analysis and comparison between two rat strains. Neuropsychopharmacology 25: 565-575.

Ouagazzal A-M, Jenck F, Moreau J-L (2001b). Drug-induced potentiation of prepulse inhibition of acoustic startle reflex in mice: a model for detecting antipsychotic activity? Psychopharmacology 156: 273-283.

Ouagazzal A-M, Moreau J-L, Pauly-Evers M, Jenck F (2003). Impact of environmental housing conditions on the emotional responses of mice deficient for nociceptin/orphanin FQ peptide precursor gene. Behav Brain Res 144: 111-117. 
Ozaki S, Kawamoto H, Itoh Y, Miyaji M, Azuma T, Ichikawa D et al (2000). In vitro and in vivo pharmacological characterization of J-113397, a potent and selective non-peptidyl ORL1 receptor antagonist. Eur J Pharmacol 402: 45-53.

Powell SB, Zhou X, Geyer MA (2009). Prepulse inhibition and genetic mouse models of schizophrenia. Behav Brain Res 204: 282-294.

Ralph RJ, Caine SB (2005). Dopamine D1 and D2 agonist effects on prepulse inhibition and locomotion: comparison of SpragueDawley rats to Swiss-Webster, 129X1/SvJ, C57BL/6J, and DBA/2J mice. J Pharmacol Exp Ther 312: 733-741.

Ralph RJ, Caine SB (2007). Effects of selective dopamine D1-like and D2-like agonists on prepulse inhibition of startle in inbred C3H/HeJ, SPRET/EiJ, and CAST/EiJ mice. Psychopharmacology 191: 731-739.

Ralph RJ, Paulus MP, Geyer MA (2001). Strain-specific effects of amphetamine on prepulse inhibition and patterns of locomotor behavior in mice. J Pharmacol Exp Ther 298: 148-155.

Ralph-Williams RJ, Lehmann-Masten V, Geyer MA (2003). Dopamine D1 rather than D2 receptor agonists disrupt prepulse inhibition of startle in mice. Neuropsychopharmacology 28: 108-118.

Ralph-Williams RJ, Lehmann-Masten V, Otero-Corchon V, Low MJ, Geyer MA (2002). Differential effects of direct and indirect dopamine agonists on prepulse inhibition: a study in D1 and D2 receptor knock-out mice. J Neurosci 22: 9604-9611.

Redrobe JP, Calo' G, Guerrini R, Regoli D, Quirion R (2000). [Nphe(1)]-Nociceptin (1-13)-NH(2), a nociceptin receptor antagonist, reverses nociceptin-induced spatial memory impairments in the Morris water maze task in rats. Br J Pharmacol 131: 1379-1384.

Richfield EK, Young AB, Penney JB (1989). Comparative distributions of dopamine D-1 and D-2 receptors in the cerebral cortex of rats, cats, and monkeys. J Comp Neurol 286: 409-426.

Roozendaal B, Lengvilas R, McGaugh JL, Civelli O, Reinscheid RK (2007). Orphanin FQ/nociceptin interacts with the basolateral amygdala noradrenergic system in memory consolidation. Learn Mem 14: 29-35.

Schlicker E, Morari M (2000). Nociceptin/orphanin FQ and neurotransmitter release in the central nervous system. Peptides 21: $1023-1029$.

Seeman P (2010). Dopamine D2 receptors as treatment targets in schizophrenia. Clin Schizophr Relat Psychoses 4: 56-73.

Swerdlow NR, Braff DL, Taaid N, Geyer MA (1994). Assessing the validity of an animal model of deficient sensorimotor gating in schizophrenic patients. Arch Gen Psychiatry 51: 139-154.
Swerdlow NR, Geyer MA (1998). Using an animal model of deficient sensorimotor gating to study the pathophysiology and new treatments of schizophrenia. Schizophr Bull 24: 285-301.

Swerdlow NR, Geyer MA, Braff DL (2001). Neural circuit regulation of prepulse inhibition of startle in the rat: current knowledge and future challenges. Psychopharmacology 156: 194-215.

Taylor MK, Ison IR, Schwarzkopf SB (1995). Effects of single and repeated exposure to apomorphine on the acoustic startle reflex and its inhibition by visual prepulse. Psychopharmacology 120: 117-127.

Viaro R, Sanchez-Pernaute R, Marti M, Trapella C, Isacson O, Morari M (2008). Nociceptin/orphanin FQ receptor blockade attenuates MPTP-induced parkinsonism. Neurobiol Dis 30: 430-438.

Visanji NP, de Bie RM, Johnston TH, McCreary AC, Brotchie JM, Fox SH (2008). The nociceptin/orphanin FQ (NOP) receptor antagonist J-113397 enhances the effects of levodopa in the MPTP-lesioned nonhuman primate model of Parkinson's disease. Mov Disord 23: 1922-1925.

Volta M, Mabrouk OS, Bido S, Marti M, Morari M (2010). Further evidence for an involvement of nociceptin/orphanin FQ in the pathophysiology of Parkinson's disease: a behavioral and neurochemical study in reserpinized mice. J Neurochem 115: $1543-1555$.

Volta M, Viaro R, Trapella C, Marti M, Morari M (2011). Dopamine-nociceptin/orphanin FQ interactions in the substantia nigra reticulata of hemiparkinsonian rats: involvement of D2/ D3 receptors and impact on nigro-thalamic neurons and motor activity. Exp Neurol 228: 126-137.

Weber M, Swerdlow NR (2008). Rat strain differences in startle gating-disruptive effects of apomorphine occur with both acoustic and visual prepulses. Pharmacol Biochem Behav 88: 306-311.

Wecker JR, Ison JR (1986). Visual function measured by reflex modification in rats with inherited retinal dystrophy. Behav Neurosci 100: 679-684.

Wei WZ, Xie CW (1999). Orphanin FQ suppresses NMDA receptor-dependent long-term depression and depotentiation in hippocampal dentate gyrus. Learn Mem 6: 467-477.

Weintraub D, Hurtig HI (2007). Presentation and management of psychosis in Parkinson's disease and dementia with Lewy bodies. Am J Psychiatry 164: 1491-1498.

Witkovsky P (2004). Dopamine and retinal function. Doc Ophthalmol 108: 17-40.

Zahodne LB, Fernandez HH (2008). Pathophysiology and treatment of psychosis in Parkinson's disease: a review. Drugs Aging 25: $665-682$.

Supplementary Information accompanies the paper on the Neuropsychopharmacology website (http://www.nature.com/npp) 